the plant under discussion, and this is very useful; not every one knows off-hand that "Kafurkachri" = Hedydium sficatum, or that "l'inée" =-Stropkanthus hispidus. Of course these are omissions we do not find in Mr. Kurz's book on the Bamboo, mentioned above; the volume on the "Eatable Funguses of Great Britain," illustrated by Mr. W. G. Smith, is not referred to, although Mr. Badham's "Esculent Mushrooms" is mentioned; while on the o: her hand such books as Loudon's "Hortus Britannicus" seem hardly to deserve a place. The Index, to which reference has already been made, is all that an index should be, and fully justifies Mr. Jackion's belief that "these entries supply a very fair starting-point for almost every question in vegetable technology."

Space will not allow us to enter further upon the merits of these Guides. Enough has, however, been said to direct attention to their importance and practical utility, and to encourage the happiest auguries for the success of the magnum opus upon which Mr. Jackson is at present engaged.

\section{JAMES BRITTEN}

\section{OUR BOOK SHELF}

Talks about Science. By the late Thomas Dunman. (London: Griffith and Farran.)

UNDER an unpretending title are here collected a number of lectures that were delivered to popular audiences, chiefly in and about London, by one whose decease, recently, in the early prime of life, has been much deplored. At the time of his death, Mr. Dunman held a post of tuition in Physiology and Animal Morphology in the Birkbeck Institution, and his labours there and elsewhere were attended with growing popularity and success. The biograpluical sketch by his friend, Mr. Charles Welsh, with which the book opens, tells of the zeal and well-directed energy with which he applied himself to overcoming the obstacles that for some time barred his path to what he considered his true life-work, viz. the teaching of science. These lectures-thirteen in number, deal with a considerable variety of topics, the mechanism of sensation, the star-lit sky, prehistoric man, volcanoes and coral reefs, atoms and molecules, and so on. The style is terse and lucid, and appears to have been carefully formed on the best models. The happy gift of relieving the strain of which many minds are conscious under mere scientific exposition, by some passing allusion to a familiar human experience, by the homely figure, the apt quotation, the play of imagination and humour, $\mathrm{Mr}$. Dunman seems to have possessed in rich measure.

The lectures entitled "Two Life Histories" and "How the Earth is Weighed and Measured," may be taken as good examples of abstruse matters expounded without technical language, and made clear for a working-class audience. Mr. Dunman's going down a coal-pit in order to qualify himself more thoroughly for his lecture on "Coal," is typical of much of his work, which in this respect (the "testifying that which he had seen") manifested, no doubt, the inspiration of his admired teacher, Huxley. Exception might be taken to a few passages in the lectures, $e g$. to the account of ocean temperatures, in "Depths of Ocean" which seems inadequate; and occasionally the author seems to affirm more confidently than the facts warrant. But as a whole the book is a good specimen of sound popularised science, and eminently engaging. As a present to a young artizan with a nascent love of science, it could not fail to be much appreciated.

\section{LETTERS TO THE EDITOR}

[The Editor dots not hold himself responsible for opinions expresscd by his correspondents. Neither can he undertake to return, or to correspond with the zeriters of, rejected manuscripts. No notice is taken of anonymous communications.

[The Editor urgently requests correspondents to keep their letters as short as possible. The pressure on his space is so great that it is impossible otherrvise to ensure the appearance even of communications containing interesting and novel facts.]

\section{The "Eira" Arctic Expedition}

I AM confident that the anticiration, contained in your article on Mr. Leigh Sinith's expedition (p. 387 ), that he has been able to make some addition to our knowledge of geography, has been realised.

'I he object of Mr. Leigh Smith's voyage was a reconnaissance to accumulate evidence respecting the advantages offered by Franz Josef Land as a base of operations for future exploration. $\mathrm{He}$ dir not intend to winter; but the accident which forced him to do so had the useful result of enabling him to extend his valuable observations over two seasons. The knowlerlge he thus acquired of the movements of ice, of its character along the shores and in the fiords for sledging purposes, of the prevailing winds and curients, of the amount of animal life to be obtained in the different months, will be very useful. 'This knowledge will be welcomed by the geographical student, and will also be of great value to future explorers. The loss of natural history collections is to be regretted, but the main object of Arctic exploration is geographical, and that object has been fully secured.

The crew of the Eira passed through the winter in perfect health. Yet they had no lime juice and, from want of warm clothing, comparatively little exercise during the coldest period. This fact must modify the theories based on the repurt of the Scurvy Committee. Here we have additional proof that it is fresh meat, and not lime juice, which is the chief preservative of health.

Another interesting point which the cruise of the Eira will throw further light upon, is the directicn from which the icebearing currents come. In a former letter I called attention to the evidence of Sir Edward Parry on this point, and to the fact that his conclusions had been corroborated by subsequent observation. Mr. Leigh Smith's voyage will furnish additional evidence upon this geographical question. As regards the advantages of Franz Josef Land as a base for future discovery, Mr. Leigh Smith has shown that in $\mathbf{1 8 8 1}$ and in $\mathbf{1} 882$ that land could easily be reached; so that we now have proof that in five consecutive years Franz Josef Land was accessible, that it has suitable bays for winter quarters, that the shore-ice in the fiords offers good sledging surface, and that there is abundance of animal life. Mr. Leigh Smith's voyage will be found to have been most useful to geographical science, and fully to have secured the object of a reconnaissance, for which it was undertaken.

2I, Eccleston Square, S.W., August 28

ClemeNTS R. MARKHAM

\section{Markree Magnetic Dip}

I HAVE made the following determinations of the magnetic dip by aid of one of Dover's excellent Kew-pattern dip-circles (No. 67). As I am observing on a pier in the open air I am not able to always use both needles simultaneously. On August I I observed within a few feet of the wall f the meridian-room. The other observations were made at a distance of over 100 feet from any wall :-

\begin{tabular}{|c|c|c|c|c|c|c|c|c|c|c|c|c|c|}
\hline 1882 & $\begin{array}{l}\text { Date } \\
\text { August }\end{array}$ & & $\ldots$ & $\begin{array}{l}\text { h. } \\
\text { I }\end{array}$ & $\begin{array}{l}\text { Tin } \\
\text { m. } \\
47\end{array}$ & & $\ldots$ & {$[70$} & Dip. & $5 \circ]$ & $\ldots$ & $\begin{array}{l}\text { Needl } \\
\text { No. }\end{array}$ & \\
\hline & , & 2 & $\ldots$ & 4 & 2 & , & $\ldots$ & & 27 & 38 & $\ldots$ & , & 2 \\
\hline & , & & $\cdots$ & 5 & 2 & , & $\ldots$ & & 25 & 16 & $\ldots$ & ," & 1 \\
\hline & ", & 3 & $\cdots$ & 2 & 50 & ", & $\cdots$ & & 26 & 27 & $\ldots$ & , & $\mathbf{I}$ \\
\hline & ," & & $\ldots$ & 3 & 56 & , & $\cdots$ & & 27 & 37 & $\ldots$ & ", & 2 \\
\hline & , & I 5 & $\ldots$ & 5 & 22 & ," & $\cdots$ & & 26 & 8 & $\ldots$ & , & $I$ \\
\hline & , , & 16 & $\cdots$ & 3 & 32 & ," & $\ldots$ & & 26 & $5^{8}$ & $\ldots$ & , & 2 \\
\hline & ", & $2 I$ & $\ldots$ & I & 37 & ,, & $\cdots$ & & 25 & 37 & $\cdots$ & ," & I \\
\hline & , & & $\ldots$ & 3 & 0 & , & $\ldots$ & & 25 & I & $\ldots$ & ," & \\
\hline
\end{tabular}

Prof. Lloyd determined the magnetic dip at this place fortyseven years ago on the same date as follows:-
I835, August $21 \quad \ldots \quad$ 2h. 22m. $72^{\circ} 4^{\prime} 48^{\prime \prime}$. 